\title{
凍結融解が木材の曲げ強度性能に 与える影響に閵する基䃟的実験
}

野田龍*1, 石橋 賢弥*2, 後藤 文彦*3

Effect of repeated freeze-thaw cycles on the bending strength of wood

Ryu NodA*1, Kenya Ishibashi*2, Humihiko Gotou*3

北海道や東北などの積雪寒冷地に建設された木製土木構造物等では, 冬期に木部材の凍結 融解が起こり得る。この凍結融解作用による木材強度の変化を把握するため, スギ正割材の 未処理材および保存処理材を対象に, 含水率および凍結融解の繰り返し回数と曲げ強度性能 の関係を評価した。

24時間を 1 サイクルとして, 未処理材, 保存処理材ともに 5 条件 $(0,15,45,75,90$ サ イクル）で凍結融解の繰り返しを行った後，曲げ試験を行った。その結果，90サイクルまで の範囲内では凍結融解の繰り返し回数に関わらず, 曲げ強さと曲げヤング係数ともに平均值 および最低值はほぼ一定のレベルに収まる傾向を示した。加えて, 凍結融解の繰り返しによ っては, 曲げ強さや曲げヤング係数が大きくなることもあり，曲げ強度性能に対する凍結融 解作用の影響は少ないと考えられた。

キーワード; 木製土木構造物, 凍結融解, 曲げ強度, 保存処理

In civil engineering structures constructed in cold snowy regions such as Hokkaido or Tohoku, repeated freezing and thawing of the wooden materials may occur in winter. To understand how the strength of wood changes because of these freeze-thaw cycles, we evaluated the bending strength of both untreated and preservative-treated Sugi (Cryptomeria japonica D. Don) timber under five regimes of freeze-thaw cycles, while varying moisture content.

Each cycle lasted 24 hours, and freeze-thaw regimes were composed of $0,15,45,75$, and

\footnotetext{
* 1 秋田県立大学木材高度加工研究所

Institute of Wood Technology, Akita Prefectural University

* 2 元秋田大学理工学部

faculty of engineering science, Akita University

* 3 秋田大学大学院理工学研究科

Department of Systems Design Engineering, Graduate School of Engineering Science, Akita University Corresponding author : R. Noda（noda@iwt.akita-pu.ac.jp）
} 
90 consecutive cycles. After each sample was subjected to a freeze-thaw regime, a bending test was carried out. There was almost no difference among the values of modulus of rupture or modulus of elasticity in samples subjected to different regimes. Moreover, as modulus of rupture and modulus of elasticity may increase after repeated freeze-thaw cycles, we concluded that the effect of the freeze-thaw cycles on the bending strength of Sugi timber is small.

Keywords; wooden civil structure, freezing and thawing, bending strength, preservative treatment

\section{1. 緒言}

北海道および東北地方などの寒冷地に生育する スギやブナ，トドマツ等の立木では，凍結によっ て樹幹が裂ける凍裂等の凍害が古くから確認さ れ，最悪の場合枯死する等，林業に大きな影響を

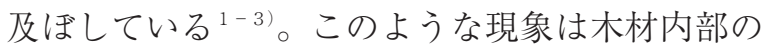
水分が凍結・膨張することによって生じるが，木 材特有の現象ではなく，例えば地盤中の水分が凍 結・膨張することによって法面構造物が持ち上げ られる被害（凍上と言う）が多く報告されている

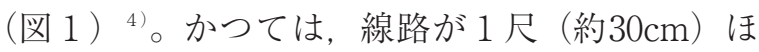
ど持ち上げられたり，住宅が傾いたりする事例が 報告されている5)。また，凍結防止剂が散布され る道路や海岸近くで使用されるコンクリート構造 物では, 塩分が影響する環境下で水分の凍結融解 を受けると, 淡水環境下よりも激しい劣化損傷を 引き起こすことが報告されている ${ }^{6,7)}$ 。これらの 現象は, 屋外で用いられる土木構造物では避けて

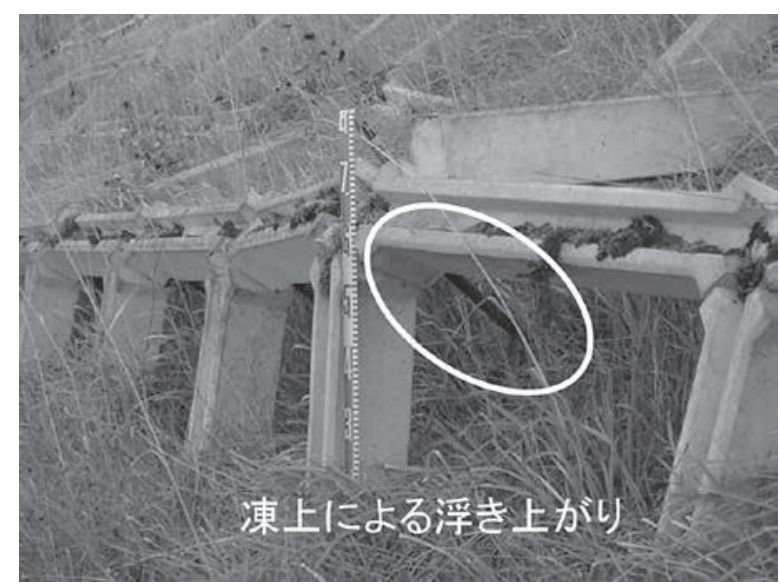

図 1 のり枠工の凍上による被害状況

Fig. 1 Damaging effects of freezing on grating crib work
は通れない問題であり, これまで様々な研究や対 策が講じられている。

木製土木構造物も例外ではなく，冬期には木材 が凍結することが確認されている（図 2)。この 凍結は気温や日射量, 風等の自然環境や設置環境 によって異なり，1日のうちに凍結と融解が生じ る場合や数日から数週間にわたって凍結状態が継 続した後, 融解する場合もある。また, 凍結融解 は構造物として供用される期間内で毎年繰り返さ れるため, 数年から数十年にわたって起こり得る ものである。そのため, 凍結融解の繰り返し作用 が構造物の強度や安定性に影響を及ぼすことが懸 念される。著者らは構造物に作用する強度のうち, 曲げ強度性能に着目し, 凍結融解が作用した時の 強度評価を進めてきた ${ }^{8-10)}$ が, これらの性能を十 分に評価するまでには至っていない。

そこで本研究では, 凍結融解を繰り返し受けた 時の木材の曲げ強度性能の変化を評価するため, 含水率と凍結融解回数を変えた曲げ試験を行っ

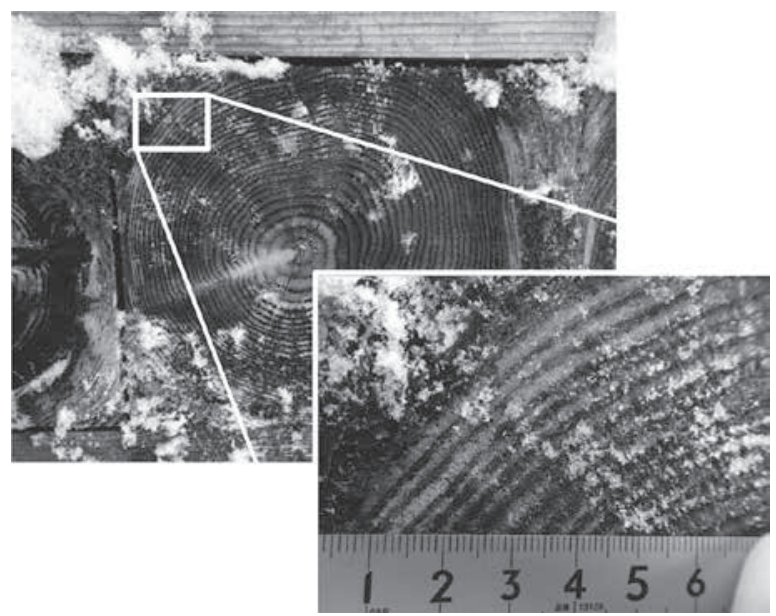

図2冬期における木材の凍結状況

Fig. 2 Freezing conditions of wood in winter 
表 1 試験条件と試験体数

Table 1 Number of test pieces

\begin{tabular}{cccccc}
\hline \multirow{2}{*}{ 処理 } & \multirow{2}{*}{ サイクル数 } & \multicolumn{5}{c}{ 目標含水率 } \\
& & $50 \%$ & $100 \%$ & $150 \%$ & $200 \%$ \\
\hline 未処理 & 0 & 5 & 5 & 5 & 5 \\
& 15 & 5 & 5 & 5 & 5 \\
& 45 & 5 & 5 & 5 & 5 \\
& 75 & 5 & 5 & 5 & 5 \\
& 90 & 5 & 5 & 5 & 5 \\
\hline 保存処理 & 0 & 5 & 5 & 5 & 5 \\
& 15 & 5 & 5 & 5 & 5 \\
& 45 & 5 & 5 & 5 & 5 \\
& 75 & 5 & 5 & 5 & 5 \\
& 90 & 5 & 5 & 5 & 5 \\
\hline
\end{tabular}

た。

\section{2. 実験方法}

\section{1 試験体}

木製土木構造物では, 用途に応じて保存処理材 と未処理材が使用されている。そこで, 本研究で は試験材として $\mathrm{L}=4,000 \mathrm{~mm}, \mathrm{H}=\mathrm{W}=40 \mathrm{~mm}$ の 秋田県産スギ（Cryptomeria japonica D. Don）の 正割材を40本用意し，うち20本を加圧注入による 保存処理を施した。なお，保存処理薬剤には(侏) シイプレザービング製マイトレック ACQ を用い た。各材から図 3 に示すように長さ $640 \mathrm{~mm}$ の試 験体を切り出した。試験体はそれぞれ 4 種類の目

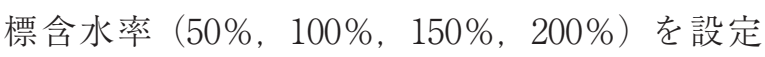
した。試験材を切り出す際，各試験体の両側から 厚さ約 $25 \mathrm{~mm}$ の小片 (図 3 中の $\mathrm{a} \sim \mathrm{f}$ ) を切り出し, 全乾法により含水率を測定した。各試験体の両側 小片の平均含水率をその試験体の注水前含水率と し，そのときの試験体重量から設定する目標含水 率の試験体重量を推定し, 各試験体の含水率を管 理した。

(株ヤスジマ製 真空・加圧含浸装置を用いて減
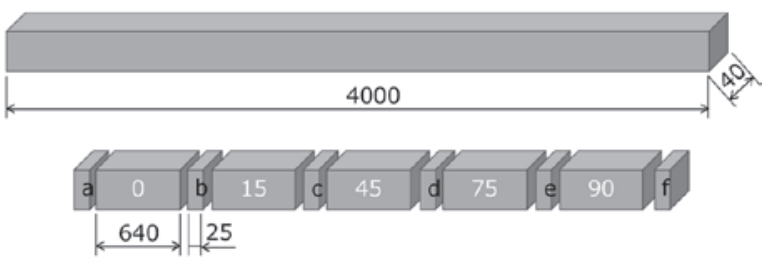

図 3 試験体の切り出し (単位 : mm)

Fig. 3 Cutout of test pieces (unit : mm)
圧注水を行った後, 目標含水率まで浸漬または自 然乾燥を行い, 概ね所定の目標含水率に達した後, 試験体の乾燥を防ぐため, 次項で示す予備実験の 結果から各試験体をラップフィルムで被覆処理 し, 凍結融解試験を行った。試験条件と各含水率 に打ける試験体数を表 1 に示す。

\section{2 凍結融解試験}

凍結融解試験を行うためには, 設定温度とその 継続時間および繰り返し回数を決める必要があ る。コンクリートでは耐凍害性を評価する試験法 として JIS A 1148 A 法抒よびB 法が規定され, 国内で広く適用されている。一方，木材を対象と した試験法はJIS には規定されておらず，どのよ うな条件で凍結融解試験を行うか決める必要があ る。そこで, 秋田県内のアメダス観測所全23箇所 の過去10年間の冬期の気温を調べ, 気温が低く, かつ 1 日の寒暖差の大きい観測地点 3 箇所を抽出 した。それらの 1 日の気温変動から, 図 4 に示寸

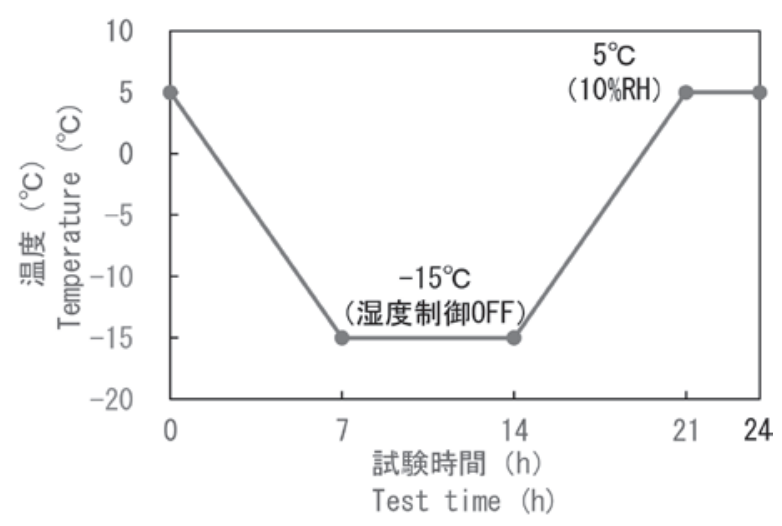

図4凍結融解の繰り返し条件

Fig. 4 Repeated freeze-thaw cycles 
凍結融解の条件を設定した。なお，凍結融解の繰 り返し回数（以下，サイクル数）は24時間を 1 サ イクルとし，０（凍結融解前），15，45，75，90 サイクルの 5 条件で試験を行った（図 3 中の白数 字)。

しかし, 凍結融解試験の実施中に試験体が乾燥 することが考えられる。そこで，試験中の乾燥防 止の処置方法を決める予備実験を行った。試験体 として断面の異なる辺長 $20 \mathrm{~mm} ， 60 \mathrm{~mm}$ スギ正割 材を供試し，木口をシリコンでシーリング処理, 試験体全体をラップフィルムで被覆処理，未処理 の 3 条件について, 断面の辺長 $20 \mathrm{~mm}$ の正割材を 図 4 に示す条件で凍結融解させた場合と断面の辺 長60mm の正割材を実験室内に静置した場合の重 量変化を測定した。さらに，断面 $20 \mathrm{~mm}$ 材の予備 実験では，試験体を旭化成ホームプロダクッ(秼) 製 ジップロック (以下，ジップロック）に入れ た場合についても行った。

結果を図 5 , 図 6 に示す。重量減少率が低い順 にジップロック梱包（重量減少率0.4\%), ラップ 被覆（同 5 〜 6\%)，シーリング（同 8〜29\%), 未処理（同18４0\%）となった。ジップロックが 最も試験中の乾燥を抑制する結果となったが，ジ ップロックは相包できる試験体長さに制限があっ たため, 本実験では, 図 7 に示寸通り, 試験体を 1 本ごとラップフイルムによる被覆処理を施すこ ととし，エスペック(陎製 恒温恒湿機を用いて凍 結融解試験を行った。

\section{3 曲げ試験}

凍結融解試験終了後，曲げ試験は，JIS Z 2101 に準拠し，(株島津製作所製 万能試験機（UHF300kNA）を用いて支点間距離 $560 \mathrm{~mm}$ ，載荷速 度 $5 \mathrm{~mm} / \mathrm{min}$ として中央集中載荷で行った。変 位は載荷点下に変位計を設置し測定した。曲げ試 験終了後，試験体中央部から長さ約 $150 \mathrm{~mm}$ の小 片を採材し，全乾法により試験時の含水率を求め た。

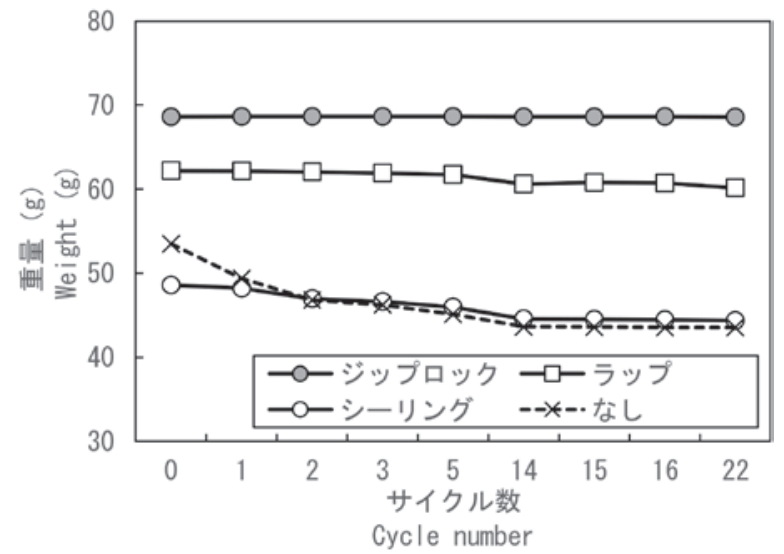

図 5 サイクル数と重量変化 (20mm 正割材, 凍結 融解)

Fig. 5 Weight change by cycle (20mm Secant, freeze-thaw)

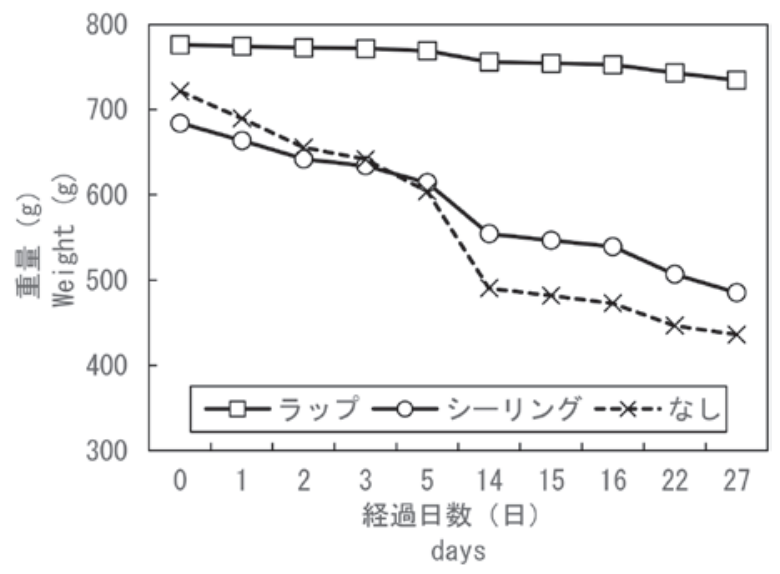

図 6 経過日数と重量変化 $(60 \mathrm{~mm}$ 正割材, 実験室 内静置)

Fig. 6 Weight change by days $(60 \mathrm{~mm}$ Secant, in the laboratory)

\section{3. 結果と考察}

\section{1 未処理材}

各サイクルにおける含水率と曲げ強さおよび曲 げヤング係数の関係を図 8 , 図 9 に示す。一般に, 繊維飽和点を超える含水率の増加は木材の力学特 性には影響しない"11) とされているが，今回の実験 では，含水率の増加に伴って，曲げ強さが低下す

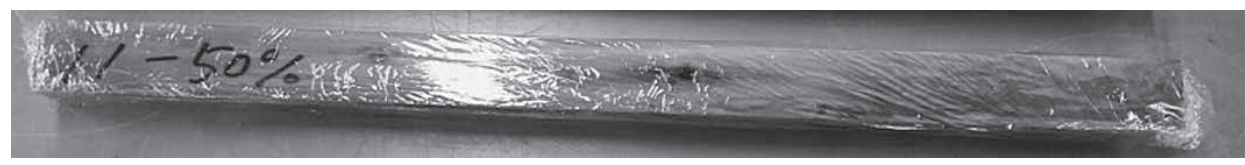

図 7 ラップ被覆した試験体

Fig. 7 Wrap coated specimens 

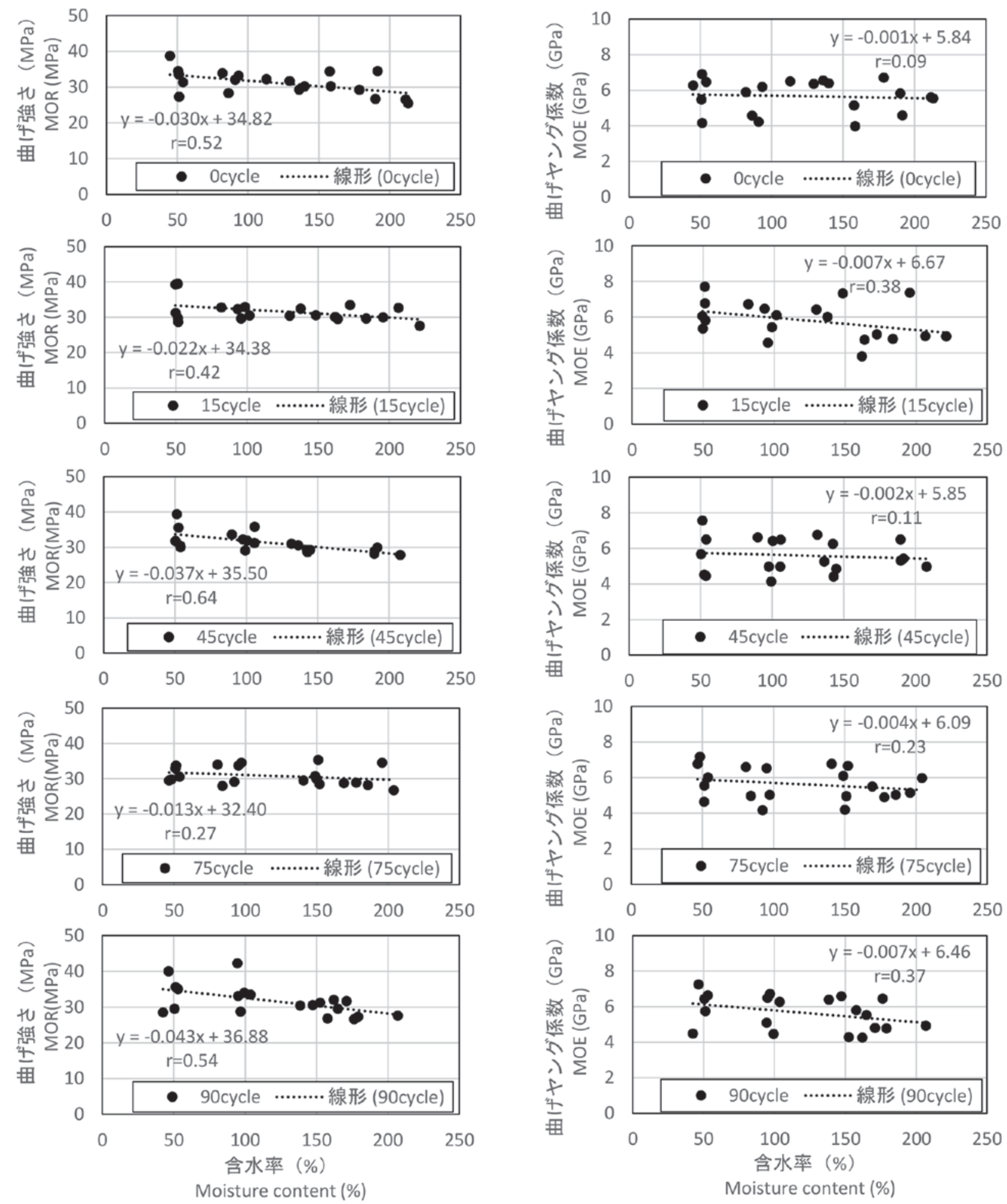

図 8 曲げ強さと含水率の関係（未処理材）

Fig. 8 Relationship between modulus of rupture and moisture content (untreatment)

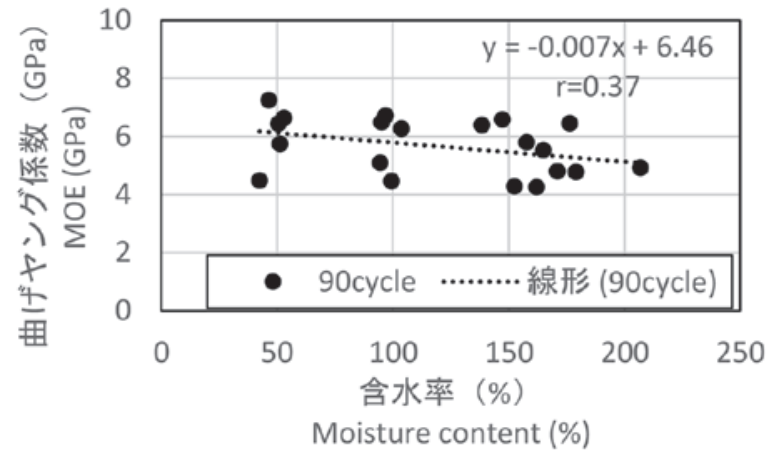

図 9 曲げヤング係数と含水率の関係（未処理材）

Fig. 9 Relationship between modulus of elasticity and moisture content (untreatment)

る傾向が見られる場合があった。一方，曲げヤン グ係数では含水率との間に相関は認められなかっ た。また，曲げ強さ，曲げヤング係数ともに最低 值はほぼ一定のレベルに収まる傾向を示した。含

水率との関係において, 曲げ強さと曲げヤング係 数に相違が見られた理由を検討するため, 曲げ試 験時の変形挙動を解析した。0サイクル時の各含 水率に扮ける荷重－変位関係を図10に示す。弾性 


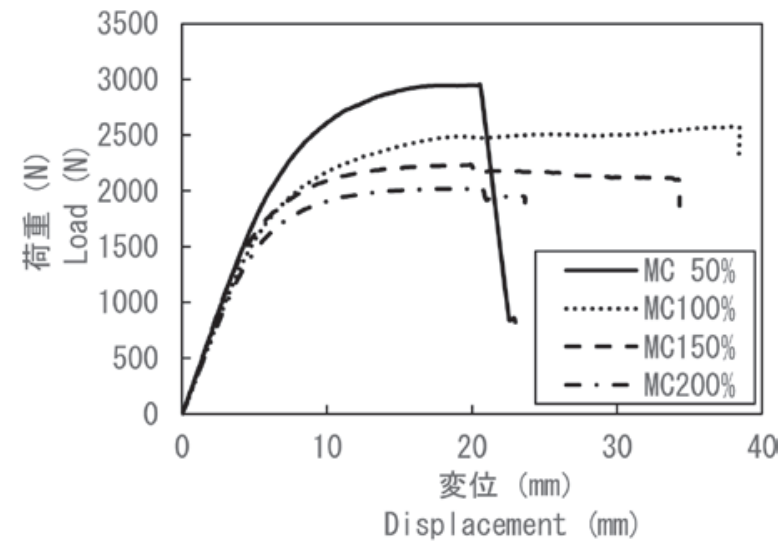

図10 含水率別の荷重一変位関係（未処理材）

Fig. 10 Relationship between load and displacement by moisture content (untreatment)

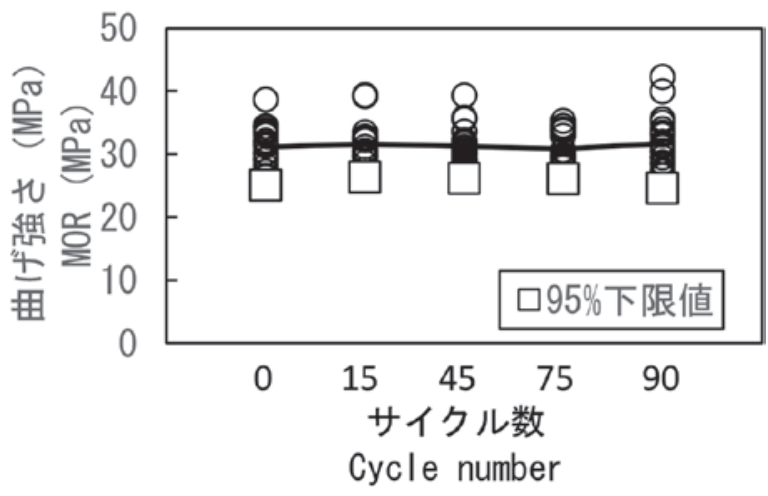

図11 サイクル別の曲げ強さ（未処理材）

Fig. 11 Modulus of rupture by cycle (untreatment)

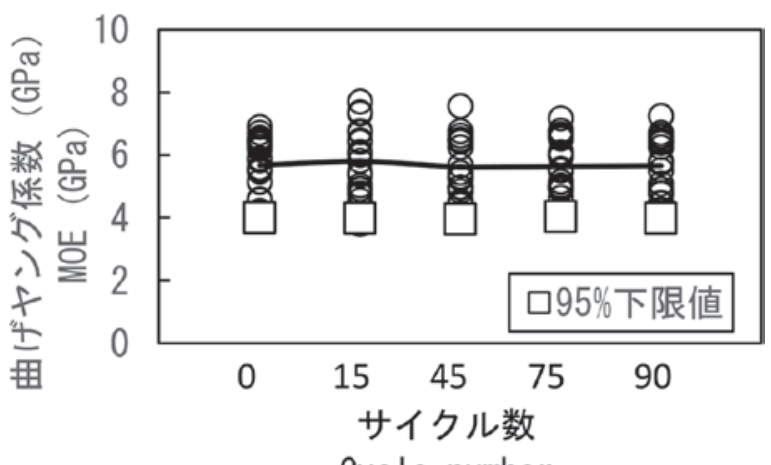

Cycle number

図12 サイクル別の曲げヤング係数（未処理材）

Fig. 12 Modulus of elasticity by cycle (untreatment)

域では，含水率の違いによる荷重変位の傾きに差 はあまり見られないが，塑性域では，含水率の増 加に伴い，より低い荷重で破断し，その変位は大 きくなる傾向を示した。このことが，曲げヤング
係数では含水率による影響がみられなかったのに 対し，曲げ強さでは含水率の違いによって差が生 じた理由と考えられる。

サイクル別の曲げ強さ及び曲げヤング係数の関 係を図11，図12に示す。図中の直線は各サイクル の平均值を結んだ線である。また，95\%信頼区間 における下限值（以下, 95\%下限值）を併記する。 凍結融解前（０サイクル）に比べ, 曲げ強さ, 曲 げヤング係数ともに凍結融解の回数を増やしても 大きな変化は見られず，0サイクルと90サイクル の間には曲げ強さ，曲げヤング係数ともに有意差 は認められなかった。また，95\%下限值について もサイクル回数による変動は認められなかった。

\section{2 保存処理材}

各サイクルにおける含水率と曲げ強さ及び曲げ ヤング係数の関係を図13, 図14に示す。曲げ強さ と曲げヤング係数ともに未処理材と同様の傾向を 示し, 双方の最低值はほぼ一定のレベルに収まる 傾向を示した。

サイクル別の曲げ強さ及び曲げヤング係数の関 係を図15, 図16に示す。曲げ強さ, 曲げヤング係 数ともに，未処理材と同様，95\%下限值はほぼ一 定となる傾向を示した。曲げ強さ，曲げヤング係 数ともに0サイクルと90サイクルの間に有意差は 認められず，また，サイクル数の違いによる95\% 下限值の変動も認められなかった。

これらのことから, 凍結融解作用を繰り返し受 けた未処理材, 保存処理材について, 曲げ強さ, 曲げヤング係数の最低值はそれぞれ一定のレベル に収まる傾向を示したが, 曲げ強さ, 曲げヤング係 数の最大值にはばらつきが散見された。先行研究 ${ }^{9}$ でも一部の結果で同様の結果が得られており, こ れは曲げ強度性能が凍結融解作用の影響を受けて いないことを示すと考えられる。また，95\%下限 值に㨟いても曲げ強さ，曲げヤング係数ともに凍 結融解の繰り返し回数による変動は認められなか った。つまり，本試験条件範囲においては曲げ強 度性能に対する凍結融解作用の影響は少ないと考 えられる。しかし，本試験で行った90サイクルは 秋田県内の気象条件から鑑みると数年程度の自然 現象と考えられる。そのため, 長期の供用が求め られる木製土木構造物を対象とする場合, より長 期間凍結融解が作用した場合について評価する必 

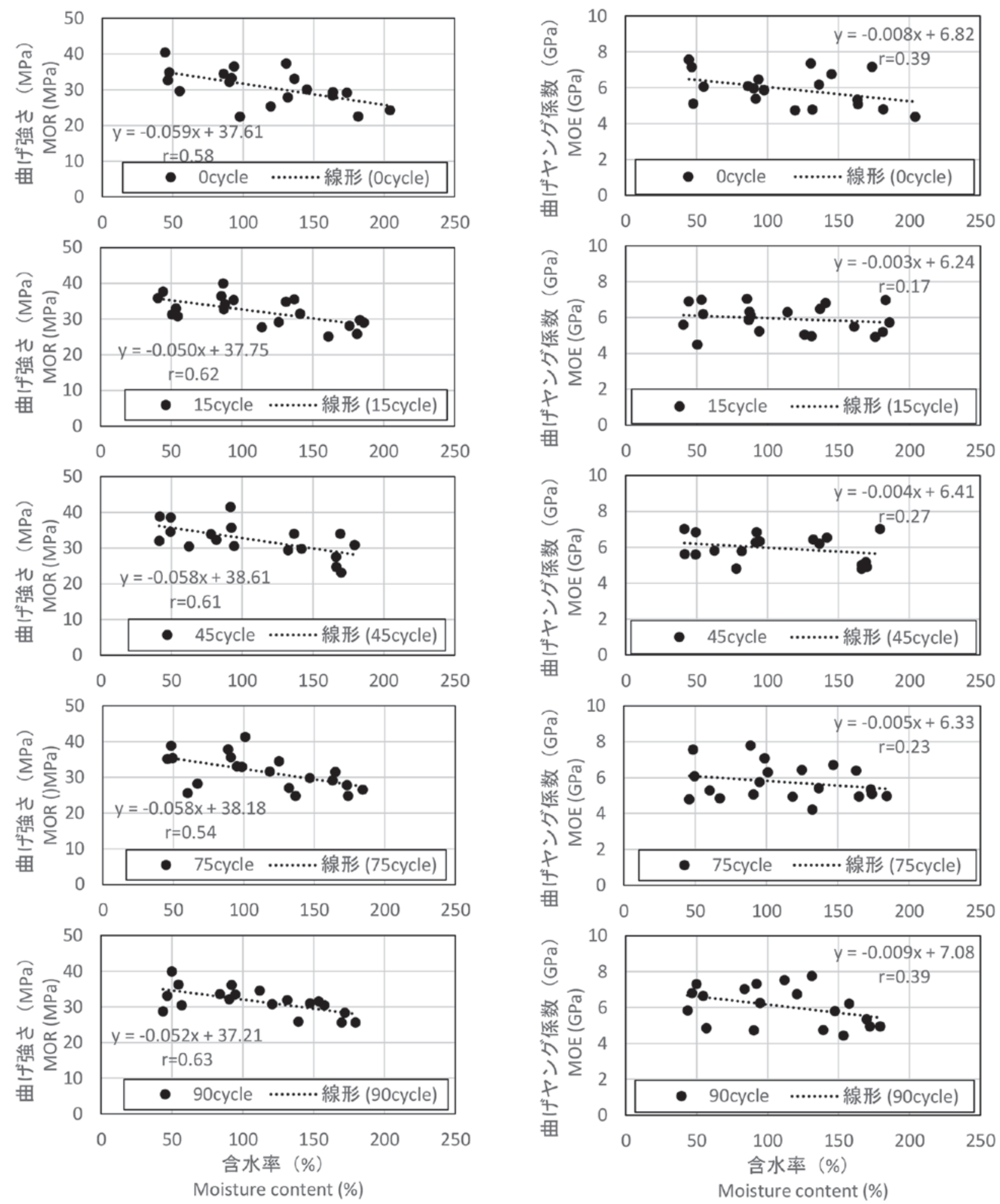

図13曲げ強さと含水率の関係（保存処理材）

Fig. 13 Relationship between modulus of rupture and moisture content (preservative treatment)

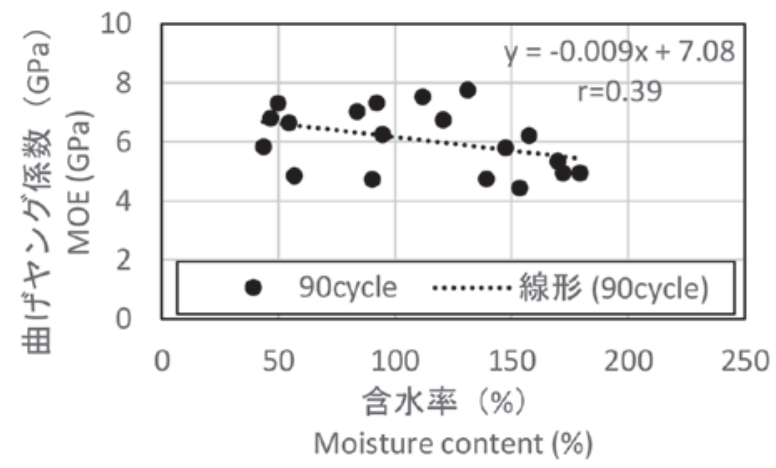

図14 曲げヤング係数と含水率の関係（保存処理材）

Fig. 14 Relationship between Modulus of elasticity and moisture content (preservative treatment) 


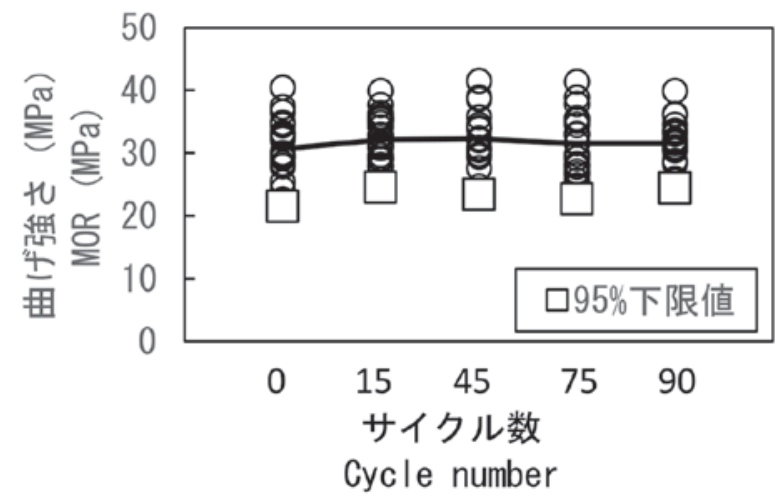

図15 サイクル別の曲げ強さ（保存処理材）

Fig. 15 Modulus of rupture by cycle (preservative treatment)

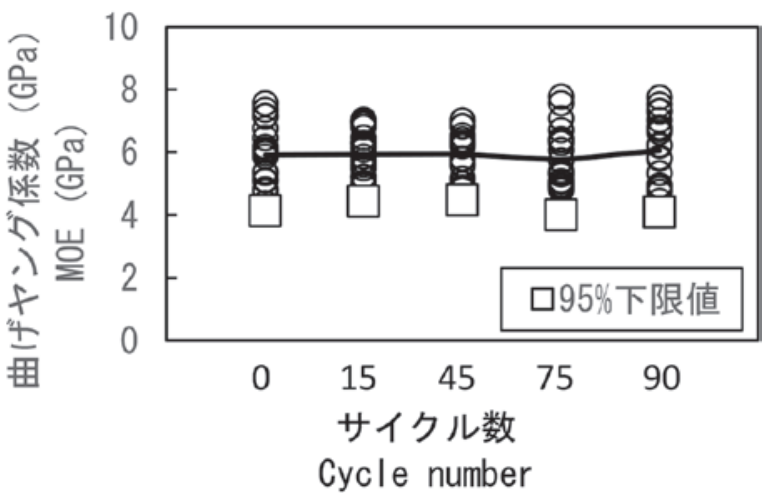

図16 サイクル別の曲げヤング係数（保存処理材）

Fig. 16 Modulus of elasticity by cycle (preservative treatment)

要がある。また，他樹種についても凍結融解の影 響を評価する必要がある。

\section{4. まとめ}

本研究では，寒冷地で発生する凍結融解作用に よる木材の曲げ強度性能を評価するため, 含水率 と凍結融解回数を変えたスギ材の曲げ試験を行っ た。その結果，以下の知見が得られた。

（1）凍結融解の回数に関わらず，曲げ強さと曲げ ヤング係数ともに平均值と最低值はほぼ一定 のレベルに収まる傾向を示した。

（2）凍結融解の繰り返しが90回までの場合，曲げ
強度性能に対する凍結融解作用の影響は少な いと考えられる。

\section{謝辞}

本研究を行うにあたり，秋田県立大学木材高度 加工研究所の山内秀文氏には試験体の注水作業で お世話になりました。また, 本研究の一部は平成 29年度江間忠研究助成によって行われました。こ こに感謝の意を表します。

\section{引用文献}

1 ）笹沼たつ：凍害を中心とする造林地の気象害 について，森林立地， 27 (2)，33-40（1985）。

2 ）今川一志：樹木の凍裂について，北方林業， 47 (6) , 16-18 (1995).

3 ）矢本智之, 田中功二, 兼平文憲: 青森県十和 田市に見られたヒバの寒害，森林防疫，51（5）, 92-96 (2002).

4 ) (社)地盤工学会北海道支部 凍上対策工と長鎖・ 設計法に関する研究委員会：斜面の凍上対策の 調査・設計マニュアル，4-13（2016）.

5 ）中谷宇吉郎:霜柱と凍上の話, 299-324(1939).

6 ）今井益隆：コンクリート構造物の凍害調査, コンクリート工学, 14 (11)，16-22（1976）.

7 ）佐伯昇, 鮎田耕一, 前川静男：北海道におけ る海岸および港湾コンクリート構造物の凍害に よる表面剥離損傷, 土木学会論文報告集, 第 327号，151-162（1982）。

8 ）野田龍, 後藤文彦, 吉田壮：繰り返し凍結作 用を受ける木材の曲げ強度に関する一考察，土 木学会第 72 回年次学術講演会, CD-ROM (2017).

9 ）近藤夏実，野田龍，藤田智郁：凍結融解を受 ける木材の曲げ強度に関する基礎的実験，第34 回日本木材保存協会年次大会，50-51（2018）。

10）石橋賢弥，野田龍：凍結融解を受ける木材の 曲げ強度，第35回日本木材保存協会年次大会， 90-91 (2019).

11）森林総合研究所監修: 改訂 4 版 木材工業八 ンドブック，114（2004）.

（2020.7 .26受付） (2020.8.11受理) 